\title{
Glomus Tumor of the Stomach: Case Report
}

\section{Midenin Glomus Tümörü: Olgu Sunumu}

\author{
Olcay AK NALBANT ${ }^{1}$, Peyker TEMiZ ${ }^{2}$, Safiye VURAL ${ }^{1}$, M. CELALETTIN KELEŞ ${ }^{3}$ \\ Departments of Pathology, ${ }^{1}$ M.H. Manisa State Hospital and ${ }^{2}$ Celal Bayar University, Faculty of Medicine and \\ ${ }^{3}$ General Surgery, M.H. Manisa State Hospital, MANISA, TURKEY
}

\begin{abstract}
Glomus tumors are benign, solitary neoplasms originating from modified smooth muscle cells of the glomus body. These tumors are rare in the gastrointestinal system. We present a glomus tumor that arose in the antrum of a 43-year-old female. During laparoscopic cholecystectomy for cholelithiasis, an antral submucosal tumor was found incidentally and total excision with wedge resection was performed. Histopathological and immunohistochemical features of this tumor were similar to those of a glomus tumor in any localization. In this report, we discuss the differential diagnosis of gastric glomus tumor.
\end{abstract}

Key Words: Glomus tumor, Stomach, Immunohistochemistry, Differential diagnosis

\section{INTRODUCTION}

Glomus tumors originate from modified smooth muscle cells of the glomus body, a neuroarterial receptor that regulates blood flow within arteries (1). Glomus tumors are most commonly found in the skin and subcutaneous tissue, but can also occur in the viscera (2-4). In the gut, they are most commonly found in the stomach (2) Gastric glomus tumors represent a rare entity $(5,6)$ and a majority of gastric glomus tumors tend to occur in the antrum $(5,7)$. These tumors are generally benign, but rare cases resulting in metastasis and death have been reported $(2,7)$.

\section{CASE REPORT}

A 43-year-old female presented with episodes of right upper quadrant pain. During laparoscopic cholecystectomy for cholelithiasis, an antral submucosal tumor was found incidentally and total excision with wedge resection was performed. The tumor was $2 \mathrm{~cm}$ in greatest diameter and the cut surface of the tumor was grey-pink and solid with a nodular appearance. The mucosa overlying the tumor was

Received : 13.04 .2009

Accepted : 30.04 .2009

\section{ÖZ}

Glomus tümörleri glomus cisimciğinin modifiye düz kas hücrelerinden kaynaklanan, benign, soliter neoplazmlardır. Bu tümörler gastrointestinal sistemde nadir görülür. Laparoskopik kolesistektomi sırasında antral submukozal alanda rastlantısal olarak saptanan ve wedge rezeksiyonla total eksizyon yapılan 43 yaşında bayan hastaya ait materyal gönderildi. Olgunun histopatolojik ve immunohistokimyasal özellikleri herhangi bir lokalizasyondaki glomus tümörünün özelliklerine benzerdi. Ancak bu olgu, mide lokalizasyonunda glomus tümörün nadir görülmesi ve ayırıcı tanıda yer alan diğer lezyonları tartışmak üzere sunulmaya değer bulunmuştur.

Anahtar Sözcükler: Glomus tümörü, Mide, İmmünohistokimya, Ayırıc1 tanı

intact. Histologically, the tumor was well-circumscribed and highly vascular, and tumor nests were separated by fascicles of smooth muscle (Figure 1A,B). The tumor cells were uniform, small, round to oval central nuclei containing stippled chromatin (Figure 1C). Nucleoli were not prominent. The cytoplasms were eosinophilic or clear. One mitosis was found in $50 \mathrm{HPF}$ (high-power fields). Immunohistochemically, the tumor cells stained diffusely positive for smooth muscle actin (SMA)(Neomarkers, CA, USA) (Figure 2A) and vimentin (Neomarkers, CA, USA) (Figure 2B), focal positive for CD34 (Neomarkers, CA, USA) (Figure 2C), and focal and weak positive for synaptophysin (Dako, Denmark) (Figure 2D). All other markers, including cytokeratins (AE1/AE3, Neomarkers, CA, USA), CD117 (Dako, Denmark), chromogranin A (Neomarkers, CA, USA), S-100 (Dako, Denmark), and desmin (Dako, Denmark) were negative.

\section{DISCUSSION}

Glomus tumor is derived from the specialized cells of the glomus apparatus (2). Vascular tumors of the gastrointestinal

Correspondence: Olcay AK NALBANT

Department of Pathology, M.H. Manisa State Hospital, MANISA, TURKEY

E-mail: olcayaknalbant@hotmail.com Phone: +90 5053874886 

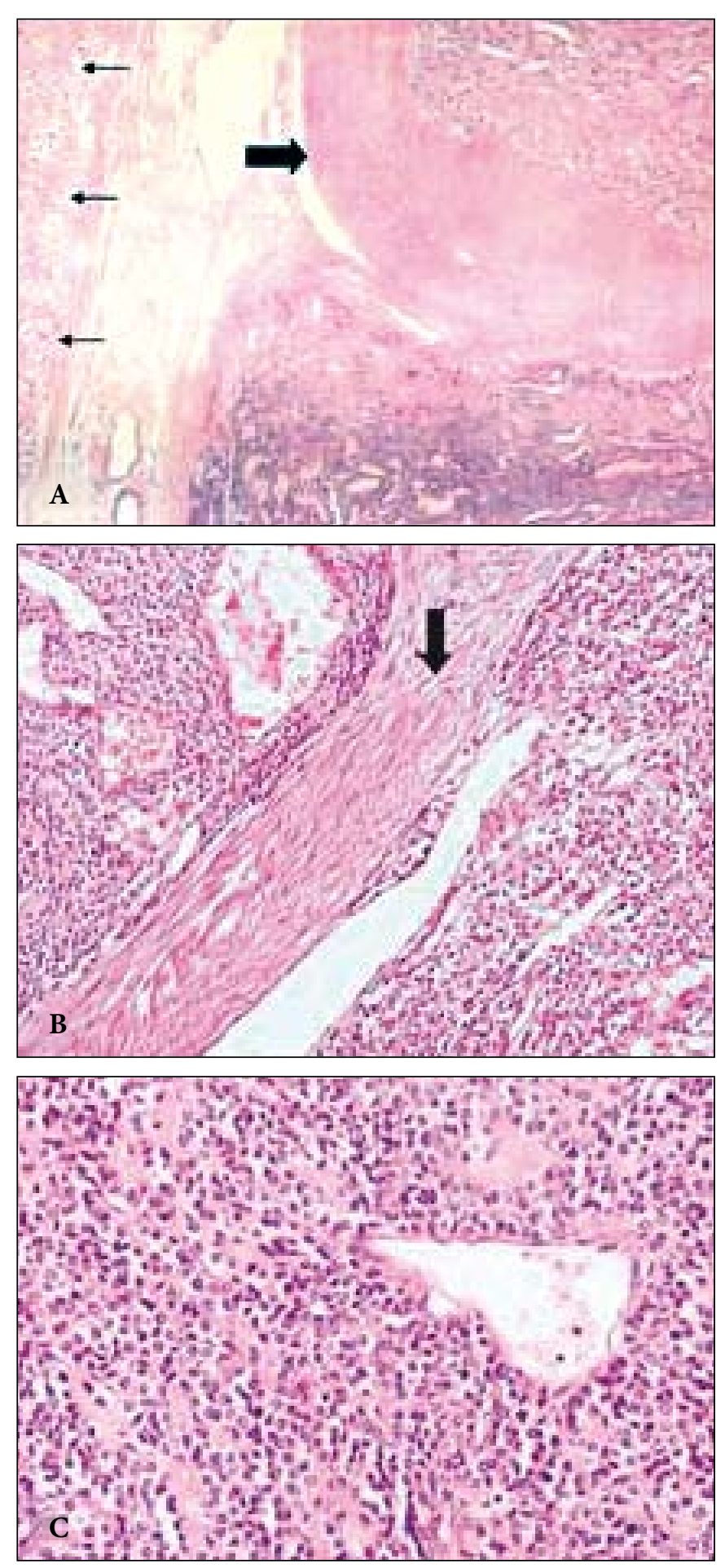

Figure 1: Histological features of gastric glomus tumor. (A) The antral mucosa overlying the tumor on the left (thin arrows) and tumor nests separated by smooth muscle fascicle on the right (thick arrow) (H\&E, x40); (B) Tumor nests, vascular component and smooth muscle (thick arrow) (H\&E, x200); and (C) Uniform tumor cells, with small, round to oval nucleus and eosinophilic or clear cytoplasms (H\&E, x400). tract are extremely rare accounting for $<2 \%$ of benign tumors, but the largest portion of such tumors are glomus tumors (1). Gastric glomus tumors represent a rare disease, and they are much less common than gastrointestinal stromal tumors (GIST) (5). Gastric glomus tumors often cause gastrointestinal bleeding, which can be acute and even life-threatening, or chronic with anemia; ulcer-like symptoms are also common $(5,7)$. Our patient had no significant medical problems associated with the gastric lesion. The tumor was found incidentally when the patient underwent laparoscopic cholecystectomy.

In the gut, glomus tumors are most commonly found in the stomach (2), and a great majority of gastric glomus tumors occurs in the antrum $(5,7)$, as seen in our patient. Miettinen et al. (7) found a significant female predominance in their study and our patient was also female.

Although massive (6) and multiple (8) gastric glomus tumors have been reported, glomus tumors are usually 2 to $3 \mathrm{~cm}$ small, (1,7), and solitary (9) lesions. The tumor in the current case was $2 \mathrm{~cm}$ in greatest diameter.

Glomus tumors are positive for SMA (2,5,7-14) and vimentin $(2,7,8,10-14)$ and negative for keratin $(1,2,5,7,9,11,12,14)$, desmin $(2,7-12,14)$, S-100 $(1,2,5,7,9,12,14)$, chromogranin A (1,7,8,10-12), and CD117 (2,5,7,11-13). In this case, tumor cells were diffusely positive for SMA and vimentin, but negative for keratin, desmin, S-100, chromogranin A, and CD117.

Immunostains with antibodies to synaptophysin $(1,11,12)$ and CD34 $(5,9,11)$ are usually negative; however, focal synaptophysin $(7)$ and/or CD34 $(7,13)$ positivity have been reported as seen in our tumor.

Gastric glomus tumors must be differentiated from epithelioid GIST, carcinoid tumor, paraganglioma and epithelioid leiomyoma.

Dilated veins or capillaries seen in epithelioid GISTs are not similarly prominent or typically seen in most glomus tumors. Epithelioid GISTs are positive for CD117 and very often (70\%) for CD34 and are more commonly negative than positive for SMA (7). This tumor was CD117 negative, focal CD34 positive and diffuse SMA positive.

Histologically, carcinoid tumor is composed of uniform round cells, similar to glomus tumor. Carcinoid cells are positive for keratins, chromogranin A and synaptophysin (7). In the presented case, the former two antigens were never expressed and the latter was rarely expressed by the glomus tumor cells. 

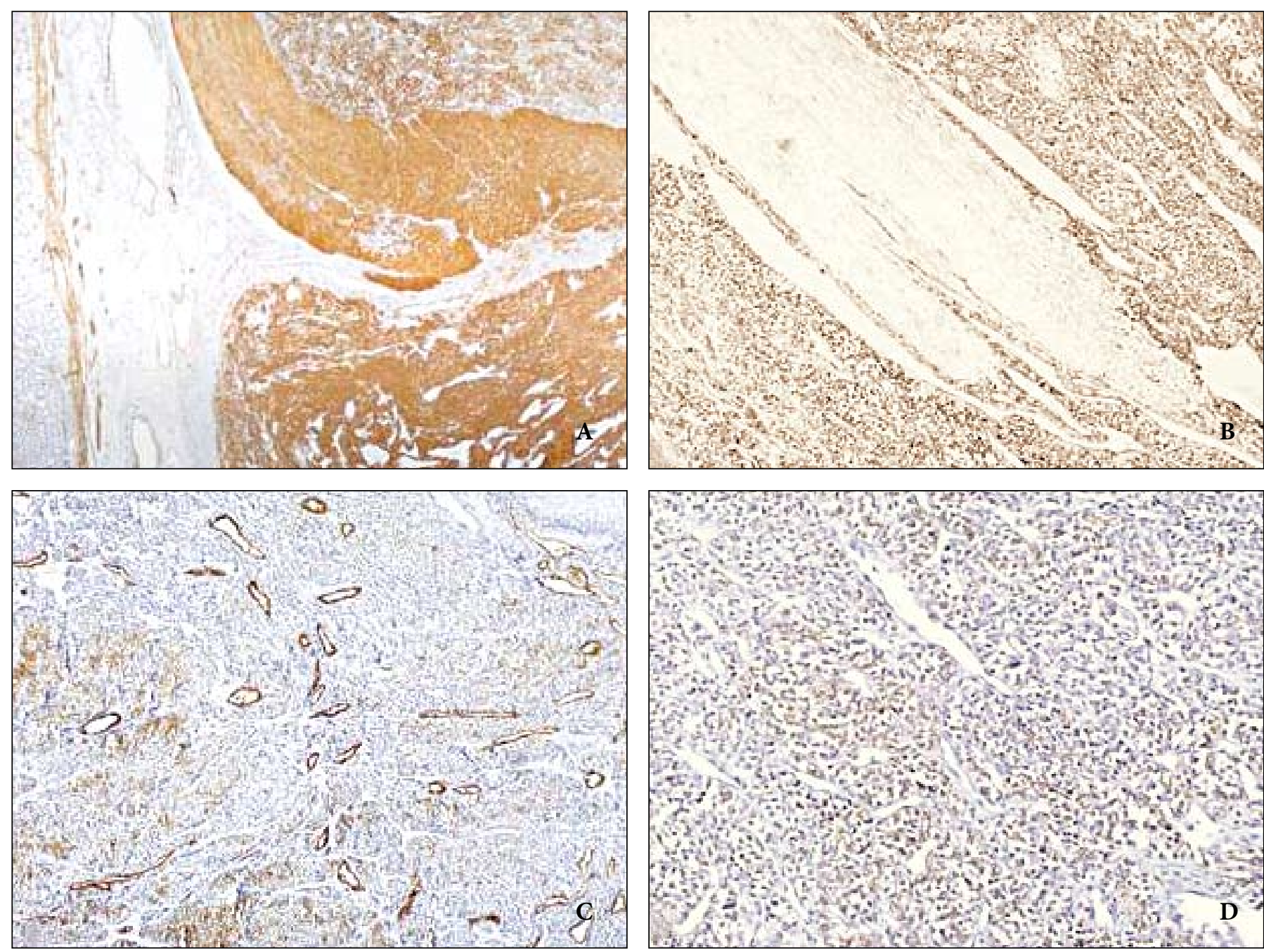

Figure 2: Immunohistochemical features of gastric glomus tumor. (A) Diffuse SMA positivity (x100); (B) diffuse vimentin positivity (x100); (C) focal CD34 positivity (x100); and (D) focal and weak synaptophysin positivity (x200).

Some variants of paraganglioma can closely mimic solid variant of the glomus tumor. However, paragangliomas are strongly positive for chromogranin A and synaptophysin. Paragangliomas also typically have S-100 protein positive sustentacular cells that are absent in glomus tumor (7). In this case, chromogranin A and S-100 were negative and synaptophysin was focal positive.

Some authors suggest that epithelioid leiomyoma and glomus tumor are indistinguishable. In any event, a smooth muscle tumor is usually positive for desmin, whereas it is often negative in glomus tumor (11), similar to our case.

Most gastric glomus tumors are benign $(2,4,5,7)$, but rare cases have resulted in metastasis and death (2). Occasionally, glomus tumors display unusual features such as large size, deep location, infiltrative growth, mitotic activity, nuclear pleomorphism and necrosis (13). Folpe et al. (13) published a proposal for classifying glomus tumor. Malignant glomus tumor is applied to tumors with a deep localization and a size $>2 \mathrm{~cm}$ in diameter, atypical mitotic figures or a moderate to high nuclear grade, and $>5$ mitoses per 50 HPF. Symplastic glomus tumor indicates tumors with high nuclear grade in the absence of any other malignant features. Glomus tumor of uncertain malignant potential is applied to those that lack criteria for malignant glomus tumor or symplastic glomus tumor but have high mitotic activity and one of the following: superficial location, large size or deep localization. Glomangiomatosis refers to tumors with histological features of diffuse angiomatosis and excess glomus cells.

The gastric site was classified as a deep site as one factor denoting potential malignancy (13). However, gastric glomus tumors should not be equated with tumors situated 
in deep peripheral soft tissues, and they should be considered a separate site-related category (7).

The tumor in our case was $2 \mathrm{~cm}$ in greatest diameter without atypia and with low mitotic activity (1 mitotic figure/50 HPF). The patient is well with no recurrence over a 2.5 year follow-up since surgery. Nevertheless, long-term follow-up of this patient is necessary.

Approximately 130 cases of gastric glomus tumor have been reported in the literature (5). This case is valuable due to its rarity. Determining of differential diagnosis and prognosis of these tumors in detail will shed further light on this entity.

\section{REFERENCES}

1. Lorber J, Kalish J, Farraye FA, Cerda S, Babineau TJ: Glomus tumor of the gastric antrum: case report. Curr Surg 2005, 62:436438

2. Kapur U, Hobbs CM, McDermott E, Mooney EE: Gastric glomus tumor. Ann Diagn Pathol 2004, 8:32-35

3. de Bruin AF, Verhoef C, den Bakker MA, van Geel A: Glomus tumor of the mesentery with atypical features: a case report. Int J Surg Pathol 2008, 16:440-442. Epub 2008 May 19.

4. Vanwijnsberghe S, Rubay R, Descamps C, Verdebout JM, Navez $B$ : A glomic tumour of the stomach treated by laparoscopy. Acta Chir Belg 2006, 106:613-615

5. Lee HW, Lee JJ, Yang DH, Lee BH: A clinicopathologic study of glomus tumor of the stomach. J Clin Gastroenterol 2006, 40:717720
6. Warner KE, Haidak GL: Massive glomus tumor of the stomach: 20-year follow-up and autopsy findings. Am J Gastroenterol 1984, 79:253-255

7. Miettinen M, Paal E, Lasota J, Sobin LH: Gastrointestinal glomus tumors: a clinicopathologic, immunohistochemical, and molecular genetic study of 32 cases. Am J Surg Pathol 2002, 26:301-311

8. Haque S, Modlin IM, West AB: Multiple glomus tumors of the stomach with intravascular spread. Am J Surg Pathol 1992, 16:291-299

9. Shim HS, Choi YD, Cho NH: Malignant glomus tumor of the urinary bladder. Arch Pathol Lab Med 2005, 129:940-942

10. Vinette-Leduc D, Yazdi HM: Fine-needle aspiration biopsy of a glomus tumor of the stomach. Diagn Cytopathol 2001, 24:340342

11. Gu M, Nguyen PT, Cao S, Lin F: Diagnosis of gastric glomus tumor by endoscopic ultrasound-guided fine needle aspiration biopsy. A case report with cytologic, histologic and immunohistochemical studies. Acta Cytol 2002, 46:560-566

12. Debol SM, Stanley MW, Mallery S, Sawinski E, Bardales RH: Glomus tumor of the stomach: cytologic diagnosis by endoscopic ultrasound-guided fine-needle aspiration. Diagn Cytopathol 2003, 28:316-321

13. Folpe AL, Fanburg-Smith JC, Miettinen M, Weiss SW: Atypical and malignant glomus tumors: analysis of 52 cases, with a proposal for the reclassification of glomus tumors. Am J Surg Pathol 2001, 25:1-12

14. Dervan PA, Tobbia IN, Casey M, O'Loughlin J, O'Brien M: Glomus tumours: an immunohistochemical profile of 11 cases. Histopathology 1989, 14:483-491 